\title{
Formation of secondary hematite and its role in attenuation of contaminants at mine tailings: review and comparison of sites in Zambia and Namibia
}

\section{Ondra Sracek *}

Department of Geology, Faculty of Science, Palacký University, Olomouc, Czech Republic

\section{Edited by:}

Jyoti Prakash Maity, National Chung

Cheng University, Taiwan

\section{Reviewed by:}

Rajesh Kumar Ranjan, Central

University of Bihar, India

Alok Chandra Samal, University of

Kalyani, India

\section{*Correspondence:}

Ondra Sracek, Department of Geology, Faculty of Science, Palacký University in Olomouc, 17. Listopadu 1192/12, 77146 Olomouc, Czech Republic

e-mail: srondra@seznam.cz
Mine tailings in African countries Zambia and Namibia have been investigated with an objective to determine the role of secondary hematite in immobilization of contaminants. Two sites, Chambishi and Mindolo, are located in the Copperbelt in Zambia with relatively humid climates and two sites, Berg Aukas and Kombat, are in Namibia, where the climate is semiarid. At the Chambishi site which is about 40 years old, a hardpan composed of hematite and gypsum has formed at a depth of about $60 \mathrm{~cm}$ and large amounts of $\mathrm{Cu}$ and $\mathrm{Co}$ have been deposited. At the much younger Mindolo site ( $<10$ year), no such hardpan was detected, but hematite is found in iron-rich bands where $\mathrm{Cu}$ and Co have also been enriched. At the Berg Aukas site, the V-rich mine tailings are $>30$ years old, but most $V$ remains in primary descloizite, embedded in a carbonate matrix while a relatively small amount of released $V$ is incorporated into hematite. In contrast, released $\mathrm{Zn}$ and $\mathrm{Pb}$ are incorporated mainly into smithsonite and cerussite, which are less stable from an environmental viewpoint. Finally, at the Kombat mine tailings $\quad<5$ years old), As released from pyrite is also incorporated into hematite, but Cu released by dissolution of chalcopyrite and bornite has precipitated as malachite, which is less stable than hematite. Water-leached concentrations of contaminants such as $\mathrm{Cu}, \mathrm{Zn}$, and $\mathrm{Pb}$ (also present in some carbonate phases) are an order of magnitude higher than water-leached concentrations of $\mathrm{V}$ and $\mathrm{As}$ which are bound to crystalline ferric minerals such as hematite and soluble only in the aqua regia fraction of sequential extraction. It seems that rapid formation of hematite under tropical climate conditions and incorporation of contaminants into this mineral phase is favorable for attenuation of released contaminants. These findings have implications at other mining sites with similar climates in Africa, South America and Asia.

Keywords: Africa, mine tailings, hematite, contaminants, attenuation

\section{INTRODUCTION}

Mine tailings can be an important source of acid mine drainage, i.e., high dissolved concentrations of sulfate, iron and other metals and metalloids in low-pH water. When the $\mathrm{pH}$ is $<3.0$, iron remains in solution or precipitates as jarosite $\left(\mathrm{KFe}_{3}\left(\mathrm{SO}_{4}\right)_{2}(\mathrm{OH})_{6}\right)$. However, at $\mathrm{pH}>3.0$ an assemblage of several $\mathrm{Fe}(\mathrm{III})$ minerals can form such as schwertmannite $\left(\mathrm{Fe}_{8} \mathrm{O}_{8}(\mathrm{OH})_{6} \mathrm{SO}_{4}\right)$, goethite $(\alpha-\mathrm{FeOOH})$, lepidocrocite $(\gamma-\mathrm{FeOOH})$, and hematite $\left(\mathrm{Fe}_{2} \mathrm{O}_{3}\right)$, (Parviainen et al., 2012). Generally, more crystalline forms of ferric minerals are formed later by aging of amorphous or poorly crystalline phases such as ferrihydrite $\left(\mathrm{Fe}_{5} \mathrm{O}_{8} .4 \mathrm{H}_{2} \mathrm{O}\right)$, (Langmuir, 1997; Filip et al., 2007). Secondary hematite has not generally been found in mine tailings deposited in moderate climate conditions. Special high temperature environment of spontaneous combustion coal piles is a notable exception (Dokoupilová et al., 2007). On the other hand, hematite has been found in mine tailings deposited under tropical climate conditions and is also relatively common in tropical soils (Langmuir, 1997; Ettler et al., 2011).
When mining wastes contain fast-neutralization minerals such as calcite, the pore water $\mathrm{pH}$ may reach $>6.0$ and neutral mine drainage is produced. In such cases, $\mathrm{Fe}$ (III) phases such as ferrihydrite may precipitate directly on the surface of sulphidic minerals, limiting penetration of oxidants to the unoxidized sulfides (Blowes et al., 2003). Also, secondary ferric minerals often incorporate large amounts of other metals and metalloids such as $\mathrm{Pb}, \mathrm{Zn}, \mathrm{As}$, and Sb (Salzsauler et al., 2005; Flakova et al., 2012).

The principal objective of this paper is to discuss the role of secondary hematite in the attenuation of contaminants such as $\mathrm{Cu}, \mathrm{Co}, \mathrm{V}$, and As at mine sites in the African countries of Zambia and Namibia. Both countries have a similar climate, but a gradient of decreasing precipitation exists from the Copperbelt in Zambia toward southwest, where Namibian sites are located at the western limit of the Kalahari Desert. The focus of the paper is on the role of hematite and common features of all sites. More detailed information about the studied sites can be found in Sracek et al. (2010a, 2014a,b). 


\section{GEOLOGY AND CLIMATE AT STUDIED SITES}

The Zambian Copperbelt is a world-renown mining region of $\mathrm{Cu}$ and Co-mineralization. The mineralization is located in the rocks of the Katanga system of the Neoproterozoic Age. They are a part of the Kibaran Mobile Belt (KMB) trending to the northeast. The geology includes argillaceous and carbonate shales, limestones, and dolomites of the Upper Roan, Mwashia, Kakontwe, and Kundelungu formations (Rainaud et al., 2005). Mineralization is from stratiform to stratabound, with chalcopyrite $\left(\mathrm{CuFeS}_{2}\right)$, bornite $\left(\mathrm{Cu}_{5} \mathrm{FeS}_{4}\right)$, Co-pyrite $\left(\mathrm{Fe}(\mathrm{Co}) \mathrm{S}_{2}\right)$, and carrolite $\left(\mathrm{Cu}(\mathrm{Co}, \mathrm{Ni})_{2} \mathrm{~S}_{4}\right)$ as the principal ore minerals (Mendelsohn, 1961). The climate in the Copperbelt is characterized by three principal seasons: a rainy season from November to April, a dry-cold season from May to June, and a dry-hot season from August to October. The total annual precipitation is more than $1300 \mathrm{~mm}$, but it falls almost exclusively during the rainy season from December to March. Two mine tailings in the Copperbelt have been studied (Figure 1): the Chambishi site, (Figure 2), representing old tailings (about 40 year) and the Mindolo site, (Figure 3), representing relatively young tailings less than 10 year old. Both mine tailings have similar composition and the principal difference is in their age. Principal sulfides of chalcopyrite, bornite, and carrolite are embedded in a carbonate matrix and the neutralization capacity of the tailings material is high (Sracek et al., 2010a). There is a potential for precipitation of secondary sulfate minerals on the surface of the mine tailings during the long dry period, which dissolve at the beginning of the rainy period (Sracek et al., 2010b).

In northeastern Namibia, there are several mining sites around Tsumeb in the Otavi Mountainland (Figure 1). This is the western limit of the Kalahari Desert where the climate is semiarid, with distinct dry and rainy periods. Precipitation is much lower

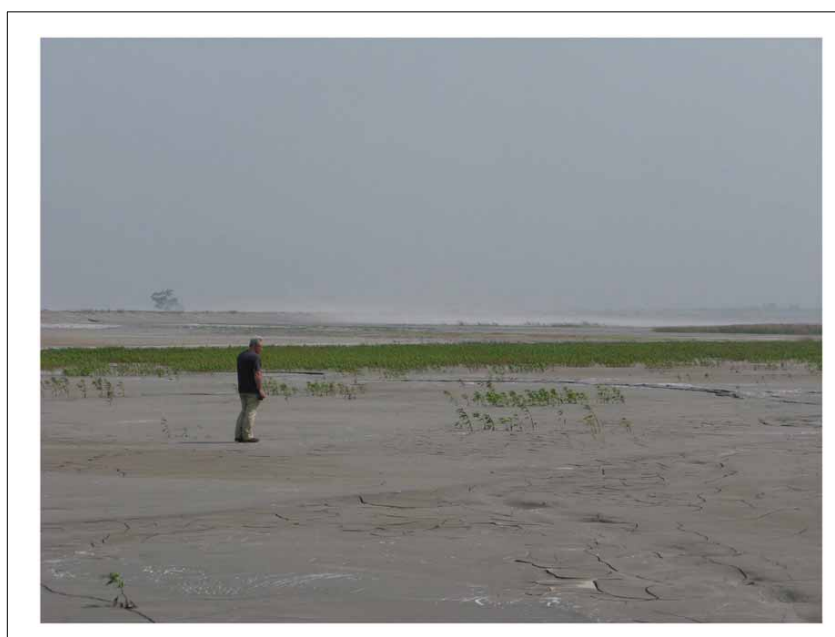

FIGURE 2 | Chambishi: global view with dust storm at the background.

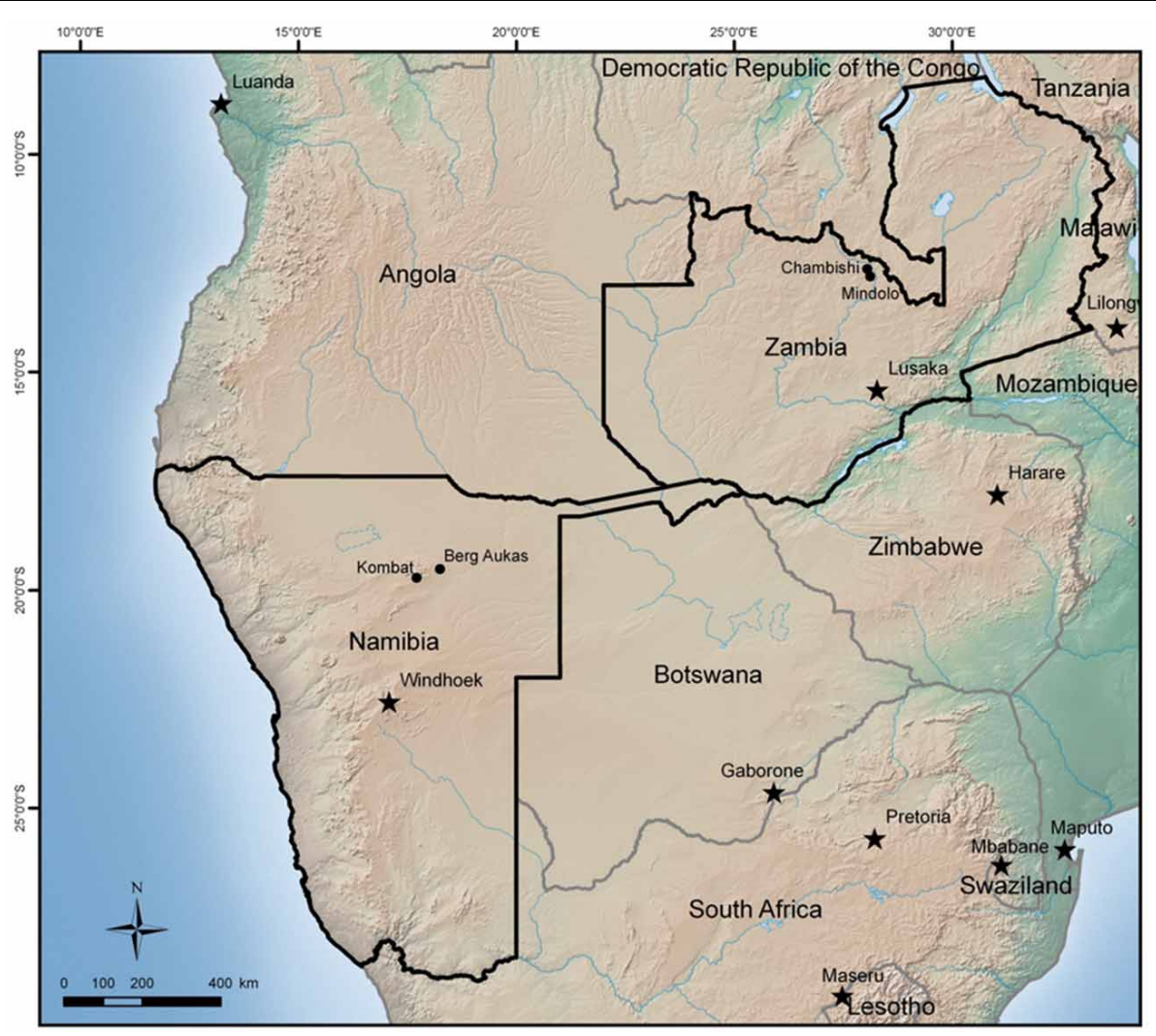

FIGURE 1 | Location of mine tailings in Zambia and Namibia. 
than in the Copperbelt, around $470 \mathrm{~mm}$, and the rainy period is from November to April as in Zambia. Berg Aukas is a mining town in northeastern Namibia (Figure 1), east of Grootfontein. Mineralization of $\mathrm{Zn}-\mathrm{Pb}-\mathrm{V}$ type, located in a dolomite host rock, was mined from 1920 to 1978 (Mapani et al., 2010). Two flotation mine tailings are located north of the previous mining area (Figure 4). The principal $\mathrm{V}$ mineral at this site is descloizite $\left((\mathrm{Pb}, \mathrm{Zn})_{2}(\mathrm{OH}) \mathrm{VO}_{4}\right)$ and the principal sulphidic minerals embedded in the carbonate matrix are sphalerite $(\mathrm{ZnS})$ and galena $(\mathrm{PbS})$. Zinc is also present in willemite $\left(\mathrm{Zn}_{2} \mathrm{SiO}_{4}\right)$, but the pyrite content is low.

The final studied site is at Kombat, which is located southwest of Berg Aukas, between Otavi and Grootfontein (Figure 1). At this site, sulfides occur as fracture fillings in the Húttenberg dolomitic rocks. Vertical ore bodies are located in the upper part of the Húttenberg Formation and terminate at the contact with the overlying slate of the Kombat Formation (Deane,

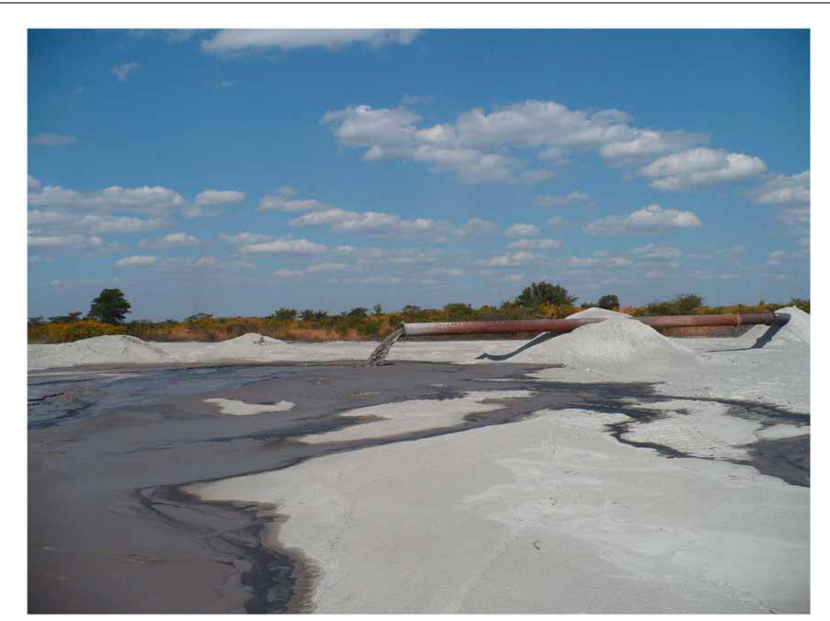

FIGURE 3 | Mindolo: deposition of fresh tailings.

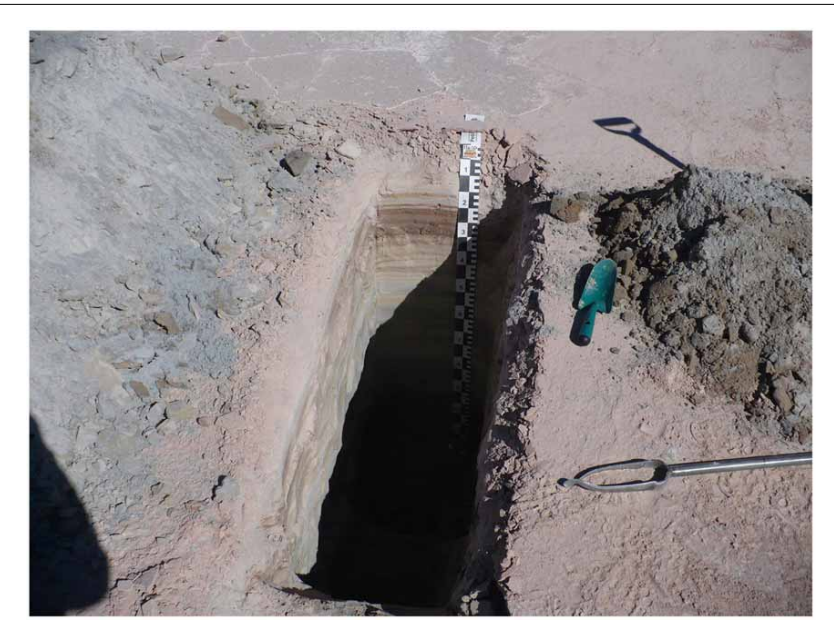

FIGURE 4 | Berg Aukas: sampling profile with reddish bands enriched in iron.
1995). The principal minerals are chalcopyrite, bornite, galena, chalcocite $\left(\mathrm{Cu}_{2} \mathrm{~S}\right)$, sphalerite, and several minerals of $\mathrm{Ge}$ such as renierite $\left((\mathrm{Cu}, \mathrm{Zn})_{11}(\mathrm{Ge}, \mathrm{As})_{2} \mathrm{Fe}_{4} \mathrm{~S}_{16}\right)$. Massive and semi-massive ore is mostly developed in brecciation zones with dolomite and associated sandstone close to the contact with slate. The mine was recently closed, but its re-opening is considered. At the flotation mine tailings (Figure 5), located close to the Kombat mine, the principal sulphidic minerals are chalcopyrite, bornite, and galena. Arsenic is generally present as an accessory in pyrite. The matrix is also composed of carbonate minerals such as dolomite, resulting in a high neutralization capacity of the mine tailings.

\section{MATERIALS AND METHODS SAMPLING OF MINE TAILINGS}

Samples of tailings solids were obtained from a hand drilling auger with an inner diameter of 4 inches. The samples were preserved in polyethylene (PE) bags. Samples from Zambian sites labeled 2, 5, and 9 are from depths of $0.6,0.9$, and $1.5 \mathrm{~m}$, respectively. Depth of Namibian samples is indicated together with sampling excavation code.

\section{BULK COMPOSITION OF SOLID SAMPLES}

The pseudo-total digests of samples were obtained by a standardized aqua regia extraction protocol in accordance with the ISO 11466 procedure (International Organization for Standartization, 1995). Standard working solutions were prepared from original certified stock solutions (MERCK) of concentration $1000 \mathrm{mg} \cdot \mathrm{l}^{-1}$ in $1 \%$ super-pure $\mathrm{HNO}_{3}$. Heavy metals and metalloids were determined using Flame Atomic Absorption Spectroscopy (FAAS, Perkin Elmer 4000 Spectrometer).

\section{X-RAY POWDER DIFFRACTION (XRD) OF HEAVY FRACTIONS OF SEDIMENTS}

XRD analyses were performed with a Philips $\mathrm{X}^{\prime}$ Pert instrument $(\mathrm{CoK} \alpha, 40 \mathrm{kV} / 40 \mathrm{~mA})$ equipped with an $\mathrm{X}^{\prime}$ Celerator detector and programmable incident and diffracted beam anti-scatter slits. Heavy minerals in each sample were concentrated by separation in 1,1,2,2-tetrabromethane before analyses.

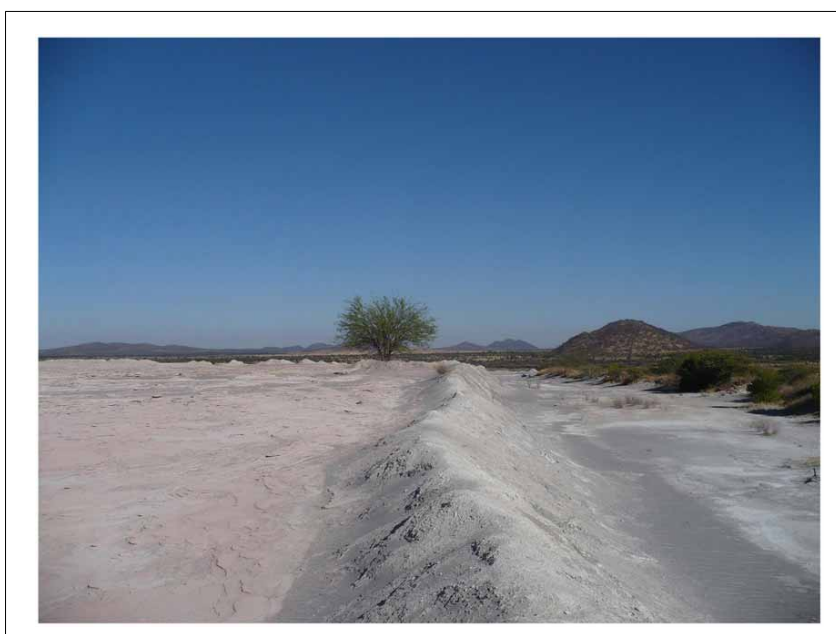

FIGURE 5 | Kombat: central plateau of mine tailings. 


\section{ELECTRON MICROPROBE}

Several solid phase samples were also studied with an electron microprobe (EMP), using a CAMECA SX100 apparatus, equipped with five crystal spectrometers and an energy dispersive $\mathrm{X}$-ray spectrum (EDS) analyzer. The analyses were performed at an accelerating voltage of $15 \mathrm{kV}$, a probe current of $10-20 \mathrm{nA}$, a spot size of $5 \mu \mathrm{m}$, and a counting time of 10-30 s.

\section{${ }^{57} \mathrm{FE} \mathrm{MÖSSBAUER} \mathrm{SPECTROSCOPY}$}

A transmission ${ }^{57} \mathrm{Fe}$ Mössbauer spectrum of the mine tailings sample, powdered in an agate mortar, was collected in constant acceleration mode with a ${ }^{57} \mathrm{Co}(\mathrm{Rh})$ source $(1.85 \mathrm{GBq})$ at room temperature. Isomer shift values were calibrated against $\alpha$ Fe foil at room temperature. The effects of non-ideal absorber thickness and variable recoil-free fractions for iron atoms in nonequivalent structural sites of different phases were expected to be within experimental error of the technique (hyperfine parameters $\pm 0.02 \mathrm{~mm} \mathrm{~s}^{-1}$, relative spectral area $\pm 2 \%$ ).

\section{SEQUENTIAL EXTRACTION}

Sequential extractions for selected bulk sediment samples were performed using the BCR procedure (Rauret et al., 1999). The following extraction scheme was used: a $0.11 \mathrm{M}$ acetic ble fractions; a $0.5 \mathrm{M}$ hydroxylamine-chloride $\left(\mathrm{NH}_{2} \mathrm{OH} . \mathrm{HCl}\right)$ step targeting the reducible fraction (mostly poorly crystalline iron/manganese oxides); an oxidisable step $\left(8.8 \mathrm{M} \mathrm{H}_{2} \mathrm{O}_{2} / 1 \mathrm{M}\right.$ $\mathrm{CH}_{3} \mathrm{COONH}_{4}$ extractable) targeting organic matter and sulfides; and an aqua regia step targeting the residual fraction. The determinations were performed in triplicates; relative standard deviations were consistently $<5 \%$. The detailed experimental scheme is given by Rauret et al. (1999).

\section{LEACHING OF SAMPLES}

Since no water was recovered from the mine tailings, $50 \mathrm{~g}$ of homogenized sample were suspended in $150 \mathrm{ml}$ of deionized water and agitated on a rotary shaker until stable readings of $\mathrm{pH}$ of $\mathrm{pH}$ and $\mathrm{EC}$, the leachate was decanted and filtered through a $0.45 \mu \mathrm{m}$ filter and then split into one subsample acidified with ultrapure $\mathrm{HCl}$ for determination of cations and metals, and a second unacidified subsample. Cations and metals were determined by FAAS (Varian AA 280 FS) under standard analytical conditions. Arsenic was determined by hydride generation AAS (HG AAS). The analytical precision of the individual solution AAS analysis was below $2 \%$. Standard reference materials BCR 483 and BCR 701 were used for quality control of the analytical data.

Anions were determined by HPLC (Dionex ICS 2000). Alkalinity was determined by titration with $\mathrm{HCl}$ using the Gran plot to determine the end point.

\section{SITE CHARACTERISTICS CHAMBISHI}

At Chambishi, the neutralization capacity of the mine tailings remains high in spite of ca 40 year of oxidation and the paste pH reaches 8.5 (Table 1; Sracek et al., 2010a). The principal secondary minerals are hematite and gypsum. They form a hardpan acid $\left(\mathrm{CH}_{3} \mathrm{COOH}\right)$ step targeting exchangeable and acid soluand electrical conductivity (EC) were obtained. After stabilization

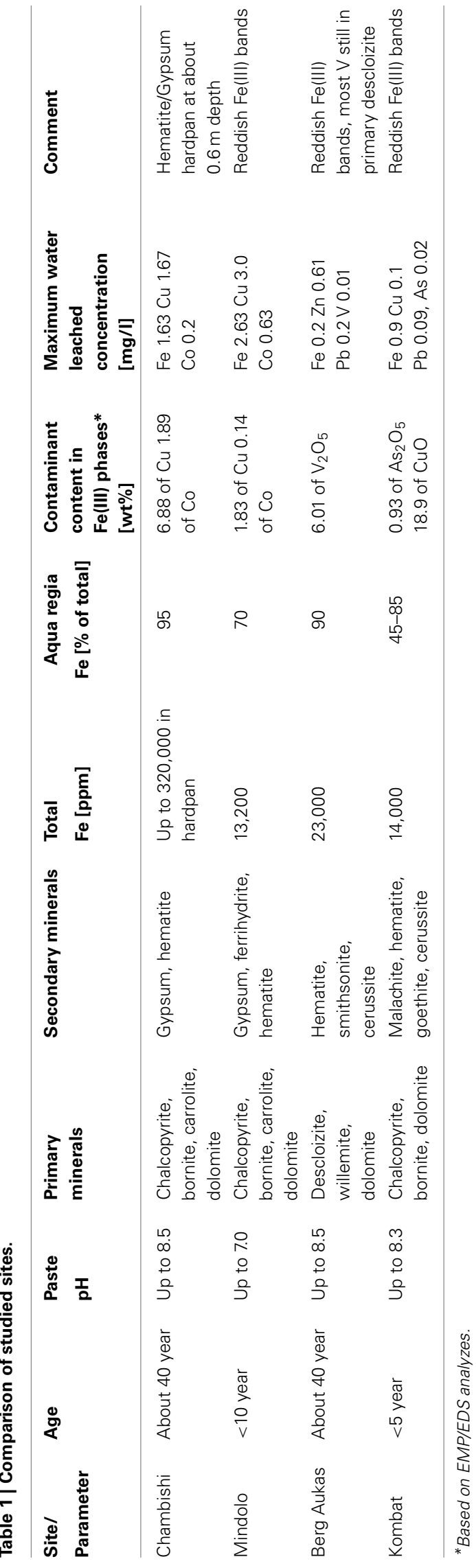

Frontiers in Environmental Science | Groundwater Resources and Management

January 2015 | Volume 2 | Article 64 | 4 
at a depth from 0.6 to $0.9 \mathrm{~m}$, where the total Fe content reaches $320,000 \mathrm{ppm}$, and a significant $\mathrm{Cu}$ and $\mathrm{Co}$ enrichment is also observed (Sracek et al., 2010a). Secondary Fe(III) phases also form rims on the surface of primary sulfides, which may contain up to $6.88 \mathrm{wt} \%$ of $\mathrm{Cu}$ and $1.89 \mathrm{wt} \%$ of Co. The beginning of the hardpan at about $0.6 \mathrm{~m}$ depth is marked by a change of color from green/gray to red, presumably corresponding to the interface between the leached surface layer and the deeper tailings enriched in ferric iron. In sequential extraction (SE), almost all iron is dissolved, but mostly in the aqua regia step (Figure 6), corresponding to hematite. A maximum amount of $\mathrm{Cu}$ is also dissolved in the aqua regia step, but high amounts are also dissolved in other steps including the acid extractable step (Figure 7), corresponding to carbonates like malachite $\left(\mathrm{Cu}_{2} \mathrm{CO}_{3}(\mathrm{OH})_{2}\right)$. Maximum concentration of $\mathrm{Fe}$ in the leachate water is $1.63 \mathrm{mg} / \mathrm{l}$, indicating a relatively high stability of secondary ferric phases, i.e., of hematite. Leached concentrations of $\mathrm{Cu}$ and $\mathrm{Co}$ are 1.67 and $0.2 \mathrm{mg} / \mathrm{l}$, respectively. The difference is caused by the additional presence of $\mathrm{Cu}$ in carbonates such as malachite, compared to Co which is present mostly in oxyhydroxides.
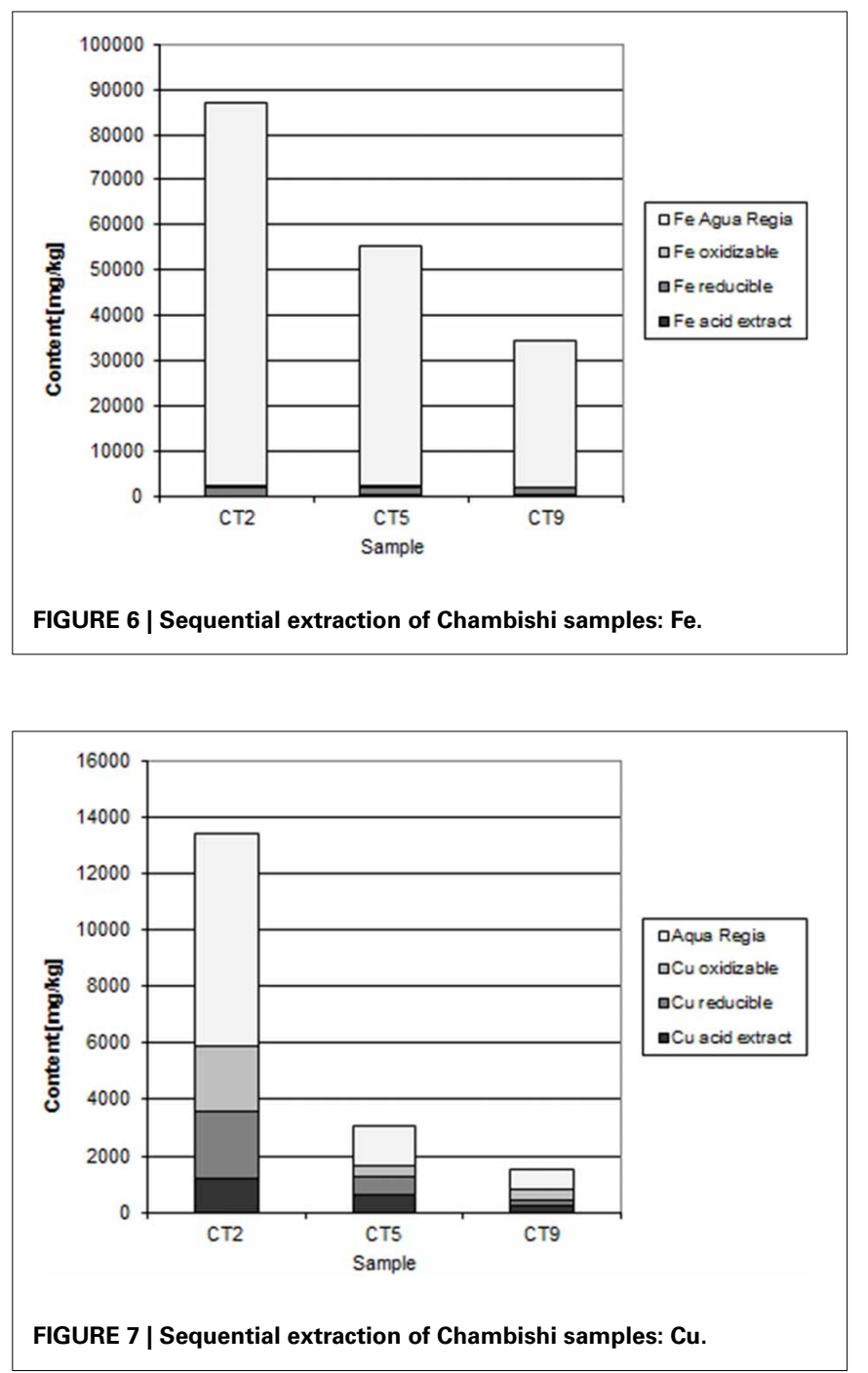

\section{MINDOLO}

The Mindolo tailings are much younger than the Chambishi tailings and a hardpan has not developed yet (Sracek et al., 2010a). In addition, conditions here are alkaline with a paste $\mathrm{pH}$ of about 7.8. The maximum iron content is about $13,000 \mathrm{ppm}$ (Table 1; Sracek et al., 2010a), and ferric Fe is mainly present in discrete reddish bands. There is no leached surface layer. Hematite is also present, but at lower amounts compared to the Chambishi site. The Fe(III) rims on the surface of the primary sulfides contain up to 1.83 wt $\%$ of $\mathrm{Cu}$ and $0.14 \mathrm{wt} \%$ of Co. In sequential extraction, the aqua regia step also dominates for $\mathrm{Fe}$, but $\mathrm{Fe}$ content is also significant in other steps (Figure 8). For $\mathrm{Cu}$, the acid extractable step is dominant at shallow depth (Figure 9). Maximum water-leached concentrations of Fe and $\mathrm{Cu}$ are 2.63 and $3.0 \mathrm{mg} / \mathrm{l}$, respectively (Table 1; Sracek et al., 2010a). They are slightly higher compared to those at the Chambishi site because there also are less stable Fe(III) phases such as ferrihydrite as expected in relatively recent mine tailings. At this site, formation of hardpan will probably occur in the future.

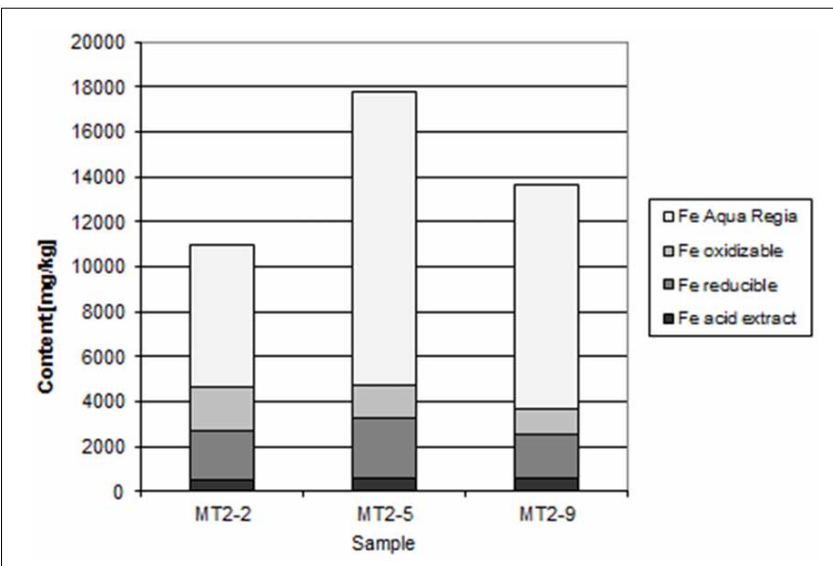

FIGURE 8 | Sequential extraction of Mindolo samples: Fe.

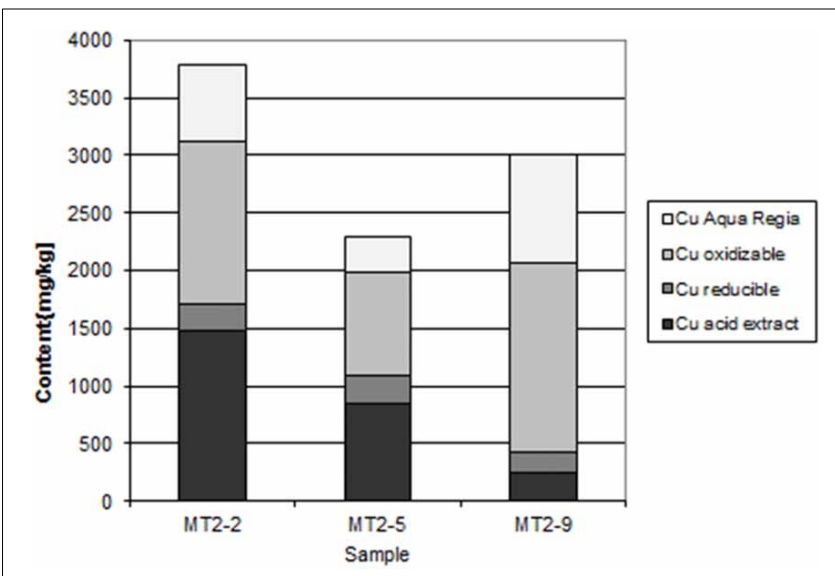

FIGURE 9 | Sequential extraction of Mindolo samples: $\mathrm{Cu}$. 


\section{BERG AUKAS}

At Berg Aukas, after $>30$ year of weathering and oxidation of tailings material to a maximum sampling depth of $2.4 \mathrm{~m}$, a large amount of $\mathrm{V}$ still remains in the primary mineral descloizite $(\mathrm{Pb}, \mathrm{Zn})_{2}(\mathrm{OH}) \mathrm{VO}_{4}$ (Sracek et al., 2014a). A part of V was mobilized and adsorbed/co-precipitated with ferric oxyhydroxides. A large amount of ferric iron is effectively bound in insoluble hematite and goethite, which contain up to $6.01 \mathrm{wt} \%$ of $\mathrm{V}_{2} \mathrm{O}_{5}$. Iron in the aqua regia fraction comprises more than $90 \%$ of the total Fe (Table 1, Figure 10; Sracek et al., 2014a). Other contaminants are $\mathrm{Zn}$, present mostly in the primary mineral willemite, $\left(\mathrm{Zn}_{2} \mathrm{SiO}_{4}\right)$, descloizite, and in secondary smithsonite $\left(\mathrm{ZnCO}_{3}\right)$; and also $\mathrm{Pb}$, which was transferred from completely dissolved galena to cerussite $\left(\mathrm{PbCO}_{3}\right)$, and is also still present in descloizite. Conditions in the mine tailings are alkaline ( $\mathrm{pH}$ up to 8.5 ) and oxidizing during the dry period, but mobility of $\mathrm{V}$ forming oxyanions is low due to the low solubility of descloizite and secondary crystalline ferric phases such as hematite (Figure 11). Respective water-leached concentrations of $\mathrm{Fe}, \mathrm{Zn}, \mathrm{Pb}$, and $\mathrm{V}$ are $0.2,0.61$, 0.2 , and $0.01 \mathrm{mg} / \mathrm{l}$. This indicates that $\mathrm{Zn}$ and especially $\mathrm{Pb}$ in secondary carbonates represent a more serious environmental risk than relatively tightly bound $\mathrm{V}$.

\section{KOMBAT SITE}

At the Kombat site which is $<5$ years old, dissolution of the most abundant primary sulfides, chalcopyrite and galena, has released $\mathrm{Cu}$ and $\mathrm{Pb}$ which have been adsorbed onto ferric minerals or precipitated as malachite, and cerussite (Sracek et al., 2014b; Vaněk et al., 2014). The mine tailings are completely neutralized, with paste $\mathrm{pH}$ up to 8.3 (Table 1). Arsenic released from arsenopyrite has been incorporated into ferric oxyhydroxides, which contain up to $0.93 \mathrm{wt} \%$ of $\mathrm{As}_{2} \mathrm{O}_{5}$, but $\mathrm{Cu}$ contents reach even $18.9 \mathrm{wt} \%$ of $\mathrm{CuO}$ (Sracek et al., 2014b). Again, a large amount of ferric iron is present as low solubility hematite, formed in a relatively short time under warm semiarid climatic conditions and soluble only in aqua regia (Figure 12), and arsenic and other contaminants in these phases are also relatively immobile (Figure 13). The presence of hematite was also confirmed by Mössbauer spectroscopy. The room-temperature ${ }^{57} \mathrm{Fe}$ Mössbauer spectroscopy spectrum (Figure 14) of an iron-rich sample (i.e., a sample from $1.0 \mathrm{~m}$ depth on profile $\mathrm{K} 1$ ) consists of one dominant magnetically-split component (i.e., a sextet with hyperfine parameters: isomer shift $\delta=0.35 \mathrm{~mm} / \mathrm{s}$, quadruple shift $\varepsilon_{Q}=-0.22 \mathrm{~mm} / \mathrm{s}$ and hyperfine magnetic field $\left.\mathrm{B}_{\mathrm{hf}}=51 \mathrm{~T}\right)$ and two minor doublets. The dominant sextet has all hyperfine parameters close to values typical for magnetically ordered hematite $\alpha-\mathrm{Fe}_{2} \mathrm{O}_{3}$ (59\% of all $\mathrm{Fe}$ atoms in this sample).

The arsenic is dissolved mostly in the aqua regia step of sequential extraction, but the reducible fraction corresponding to low crystallinity ferric minerals and the oxidizable fraction corresponding to As-rich pyrite are also significant. Respective water-leached concentrations of $\mathrm{Fe}, \mathrm{Cu}, \mathrm{Pb}$, and As are $0.9,0.1$, 0.09, and $0.02 \mathrm{mg} / \mathrm{l}$ (Table 1; Sracek et al., 2014b). Again, Cu and $\mathrm{Pb}$ partly bound in carbonate minerals represent a more serious environmental risk than As bound in crystalline low solubility Fe(III) oxyhydroxides.

\section{GENERAL FEATURES OF STUDIED SITES}

At all studied sites, the principal contaminants incorporated into hematite, being $\mathrm{Cu}$ and $\mathrm{Co}$ at the Zambian sites, and $\mathrm{V}$ and As at the Namibian sites, show relatively low mobility.

At the Chambishi site, with high temperatures and high seasonal precipitation, hardpan composed mostly of hematite and gypsum has incorporated large amounts of $\mathrm{Cu}$ and $\mathrm{Cu}$. Leached $\mathrm{Cu}$ concentrations in some samples are still relatively high, but this is due to its presence in more soluble malachite. The hardpan also limits infiltration into the deep mine tailings and contributes to the ponding of rain water in the rainy period (Sracek et al., 2010a). Almost all Fe(III) is in hematite (Table 1, Figure 6).

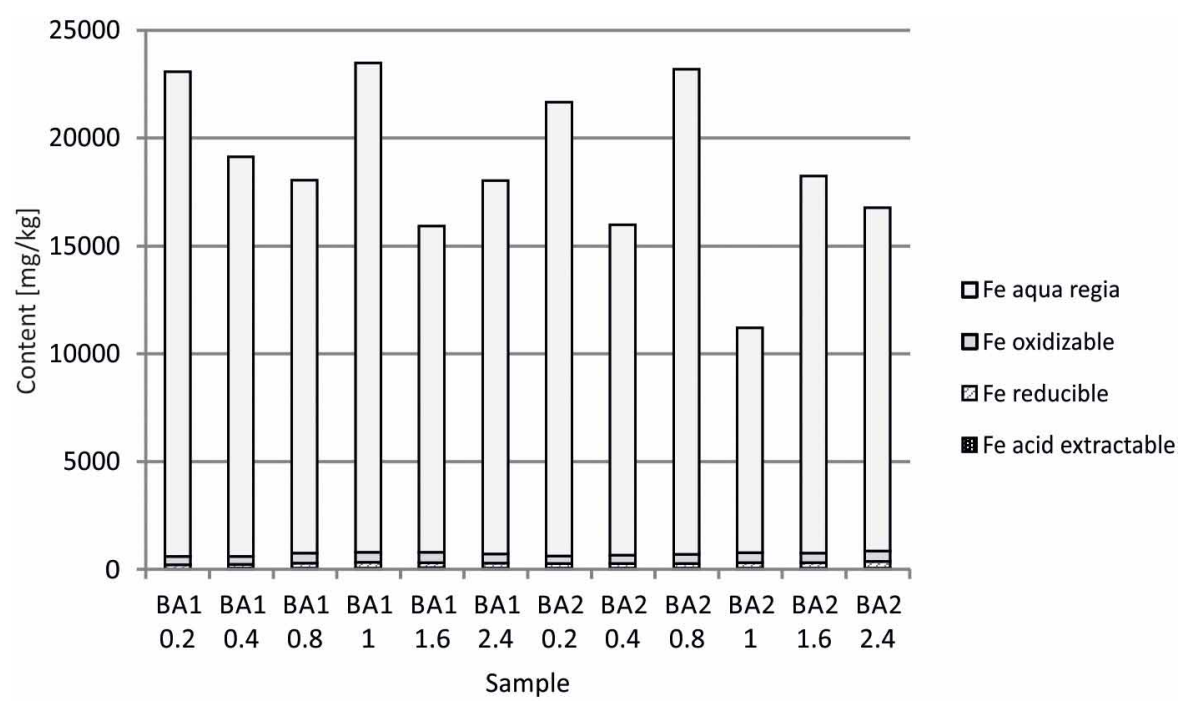

FIGURE 10 | Sequential extraction of the Berg Aukas samples: Fe. 


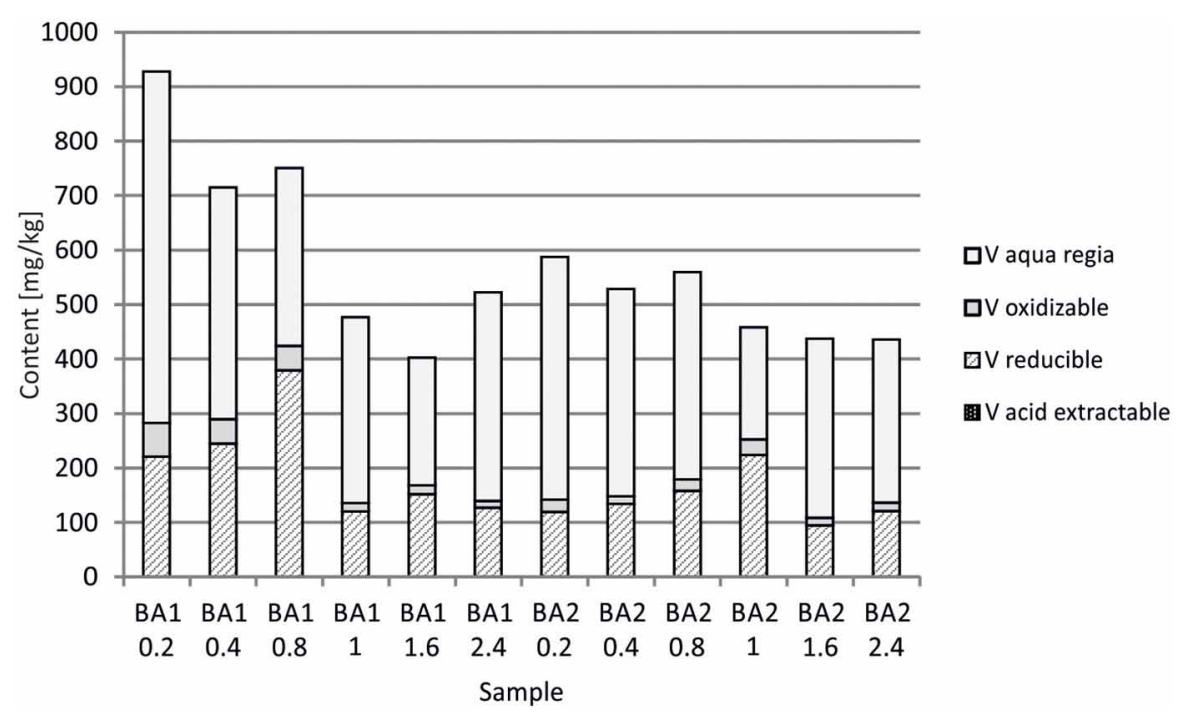

FIGURE 11 | Sequential extraction of the Berg Aukas samples: V.

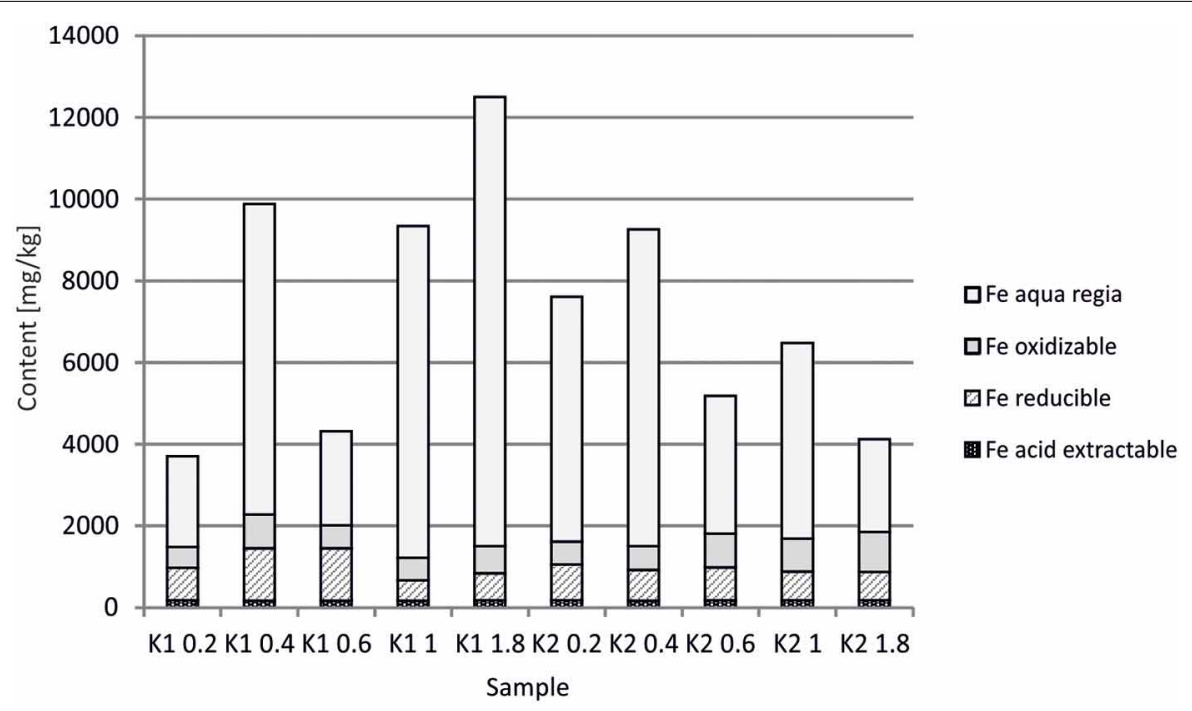

FIGURE 12 | Sequential extraction of samples from Kombat: Fe.

At Mindolo with similar climatic conditions as Chambishi and containing younger mine tailings, there are also low crystallinity $\mathrm{Fe}(\mathrm{III})$ phases, but $\mathrm{Fe}$ in the aqua regia fraction, corresponding to hematite and goethite, comprises about $70 \%$ of the total $\mathrm{Fe}$ (Table 1). In some places, ferric minerals have precipitated on the surface of sulphidic minerals, which were completely dissolved later and only their coatings remain (Figure 15). Water-leached concentrations are comparable to those from Chambishi or are slightly higher as a consequence of lower crystallinity of minerals in younger mine tailings.

In Berg Aukas with high temperature and relatively low seasonal precipitation, most of the $\mathrm{V}$ remains in primary descloizite and released $\mathrm{V}$ was incorporated into ferric oxide and hydroxides, which were later transformed to hematite, soluble only in aqua regia (Sracek et al., 2014a). It has a very low solubility and waterleached concentrations of $\mathrm{V}$ are generally low (Table 1). This is a favorable situation because $\mathrm{V}$ present as an oxyanion has high mobility under high $\mathrm{pH}$, oxidizing conditions (Cornelis et al., 2008).

At the Kombat site, with similar climatic conditions as at Berg Aukas, most of the As is bound to crystalline $\mathrm{Fe}(\mathrm{III})$ oxyhydroxides (Sracek et al., 2014b). The site is less than 5 years old, but As is immobile due to its link to crystalline hematite and goethite which are soluble only in aqua regia. Hematite comprises about $60 \%$ of the total $\mathrm{Fe}$, as indicated by ${ }^{57} \mathrm{Fe}$ Mössbauer spectroscopy (Figure 14). Again, $\mathrm{Cu}$ and $\mathrm{Pb}$ partly bound to carbonate minerals are more mobile. 


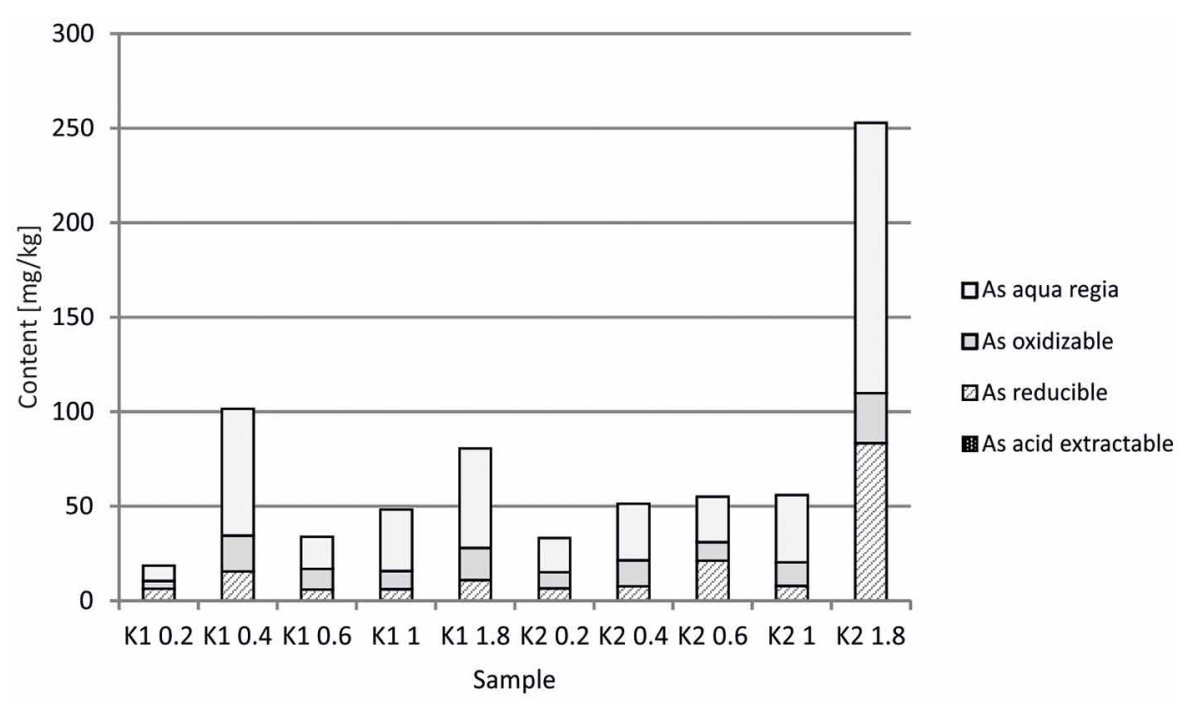

FIGURE 13 | Sequential extraction of samples from Kombat: As.

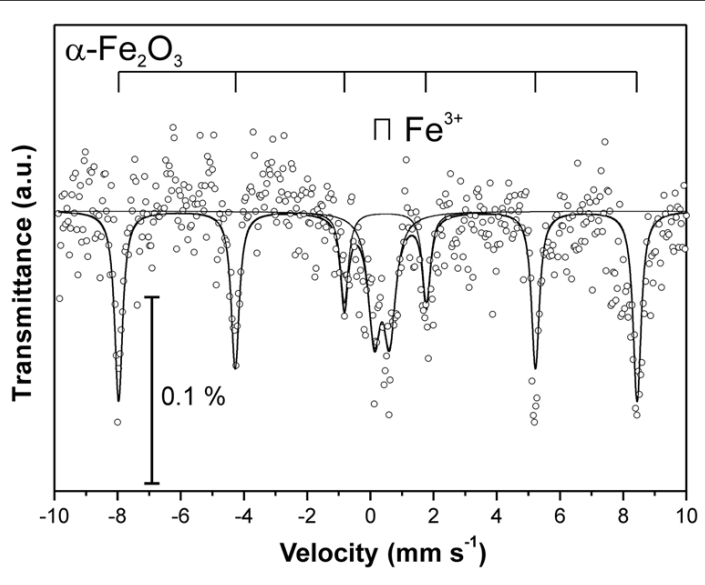

FIGURE 14 | Hematite determined by Mössbauer spectroscopy at Kombat site.

At old Chambishi site, there is $94.5-97.3 \%$, average $95.0 \%$ of Fe and $46.8-55.9 \%$, average $49.7 \%$ of $\mathrm{Cu}$ in aqua regia step. At young Mindolo site there is $57.9-73.6 \%$, average $68.1 \%$ of Fe and $14.9-31.6 \%$, average $21.6 \%$ of $\mathrm{Cu}$ in aqua regia step. At old Berg Aukas site, Fe in aqua regia step is in the range 92.9-97.3\%, average 95.9 and $\mathrm{V}$ is in the range $44.6-75.7 \%$, average $65.7 \%$, Finally, at young Kombat site, Fe in aqua regia step is in the range 55.2$89.7 \%$, average $72.3 \%$ and As is in the range $42.1-67.2 \%$, average $57.4 \%$. Differences in aqua regia Fe between old and young sites are significant at $p=0.01$.

Hematite is formed by aging of lower crystallinity ferric phases and is common in warm climate soils. It is the chief oxyhydroxide in red-bed sediments (Langmuir, 1997). It has been found in several mine tailings, generally located in tropical and subtropical regions with distinct rainy and dry periods. This is a typical mineral of cemented layers (hardpans) in old mine tailings. At Taxco, central Mexico, mine cemented layers rich in hematite were found in the oxidation zone of mine tailings (Romero et al., 2007). At Cleveland, New Mexico, USA, hematite and goethite were found in low-pH, highly oxidized mine tailings (Boullet and Larocque, 1998). Hematite was also found at Touiref, Tunisia, in an assemblage of Fe-oxyhydroxides (Othmani et al., in press). On the other hand, hematite has not been found in some mine tailings located in semi-arid regions, e.g., Iron King Superfund Site in Arizona (Hayes et al., 2014), where ferrihydrite has been persistent for many years.

Adsorption of As on hematite was studied by Singh et al. (1996) and Giménez et al. (2007). Both studies confirmed hematite as an efficient adsorbent of As(V). As expected, As $(\mathrm{V})$ adsorption decreased with increasing $\mathrm{pH}$, but adsorption was still significant up to $\mathrm{pH}$ 10. In laboratory studies, arsenate was found to form bridging bidentate complexes on two adjacent singlycoordinated groups on each of two distinct terminations at the hematite surface (Catalano et al., 2007). Adsorption of As(V) onto goethite also decreased with increasing $\mathrm{pH}$ and the range of maximum sorption for As(III) was between $\mathrm{pH} 5$ and 9 (Manning et al., 1998; Dixit and Hering, 2003). Competition with other oxyanionic species may shift the adsorption maximum for As(V) to lower $\mathrm{pH}$ values (Dixit and Hering, 2003). A recent study of Bolanz et al. (2013) confirmed incorporation of As into hematite in the form of angelellite $\left(\mathrm{Fe}_{4} \mathrm{As}_{2} \mathrm{O}_{11}\right)$ crystals, which epitaxially intergrow along the (210) plane of hematite. Structural incorporation into goethite and hematite for $\mathrm{Pb}$ was also confirmed by $\mathrm{Vu}$ et al. (2013). The incorporation occurred primarily during the initial stage of ferrihydrite crystallization and $\mathrm{Pb}$ did not replace $\mathrm{Fe}$, but was incorporated into defects and nanopores. At the currently-studied sites, the exact mechanism of contaminant binding (i.e., adsorption vs. structural incorporation) has not yet been determined and should be addressed in more detailed future studies. 


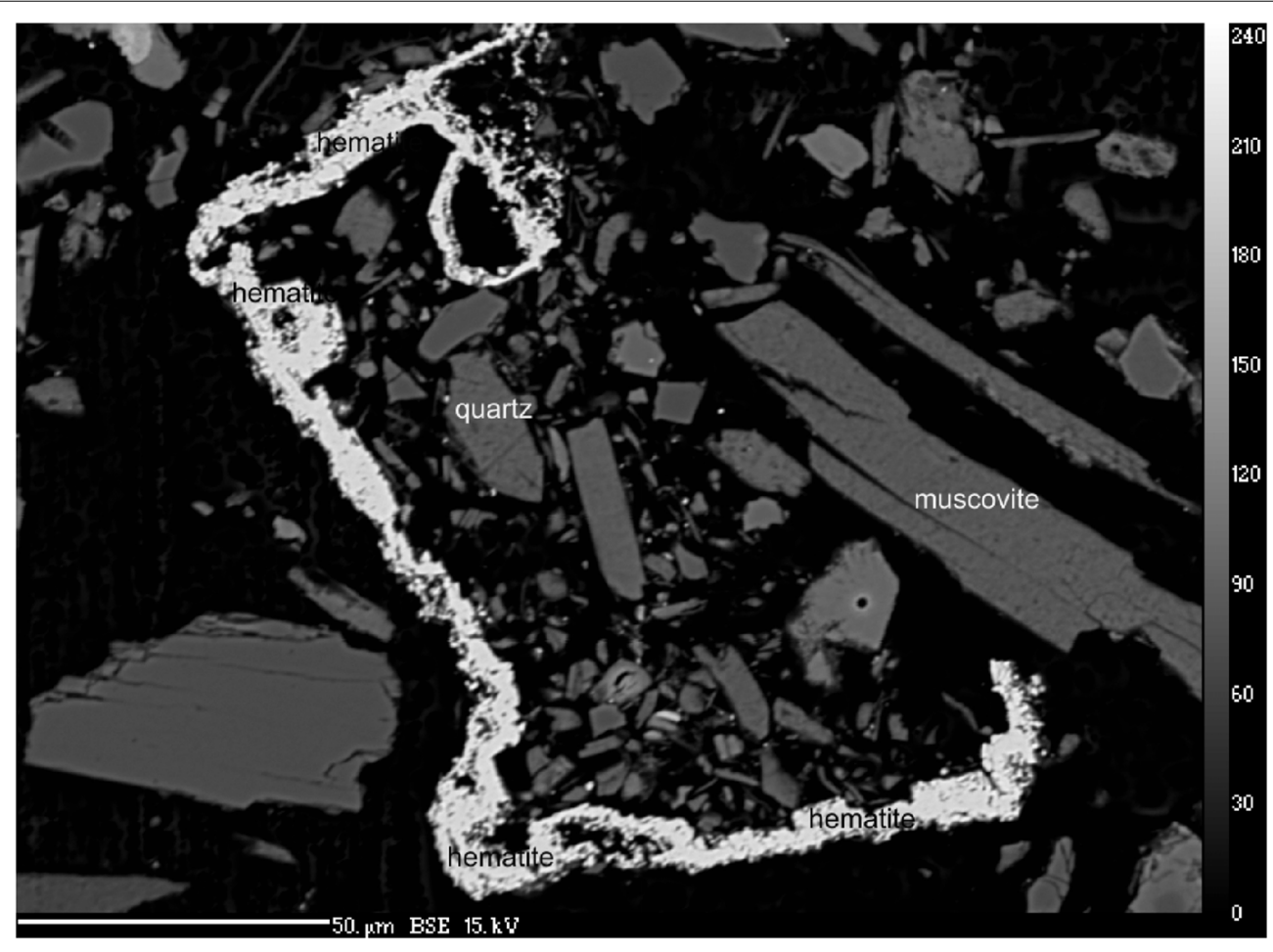

FIGURE 15 | Hematite determined by Electron Microprobe (EMP) in backscattered mode at Mindolo site, see explanation in text.

Compared to tightly hematite-bound contaminants, $\mathrm{Zn}$ and $\mathrm{Pb}$ incorporated into carbonates such as smithsonite and cerussite can be mobilized under low-pH conditions such as those found in human gastric acids (Meunier et al., 2010; Jamieson, 2011). The same applies for malachite, which is a common $\mathrm{Cu}$ mineral in Cu-rich mining wastes (Dold and Fontboté, 2001, 2002). This is also consistent with gastric bioavailability of contaminants in mine tailings from Rosh Pinah in southern Namibia, where As linked to Fe(III) oxyhydroxides shows low bioavailability, while $\mathrm{Zn}$ and $\mathrm{Pb}$ in carbonates show high bioavailability (Nejeschlebová et al., in review). In summary, formation of secondary hematite in mining waste is a favorable process, which may attenuate contaminants released into pore water. In some mine tailings, primary sulfides have been completely dissolved and replaced by secondary minerals such as hematite. It seems that formation of hematite is very fast under tropical climate conditions with distinct rainy and dry periods typical for countries such as Zambia and Namibia. Immobilization of contaminants in hematite has implications for other mining sites around the world which are located in regions with similar climatic conditions, e.g., in Africa, South America, and Eastern Asia.

\section{CONCLUSIONS}

Mine tailings in Zambia and Namibia are located in high temperature, but variable precipitation environments. Two sites, Chambishi and Mindolo, are located in the Copperbelt in northern Zambia with a relatively humid climate (precipitation > $1000 \mathrm{~mm}$ ) and two sites, Berg Aukas and Kombat, are in northeastern Namibia, where the climate is semiarid (precipitation $<500 \mathrm{~mm})$.
At the Chambishi site, which is about 40 year old, a hardpan composed of hematite and gypsum had formed at a depth of about $60 \mathrm{~cm}$, where large amounts of $\mathrm{Cu}$ and $\mathrm{Co}$ are found, but hematite is present down to a depth of about $3 \mathrm{~m}$.

At the much younger Mindolo site ( $<10$ years old), no hardpan was detected, but hematite is found in iron-rich bands where enrichment in $\mathrm{Cu}$ and Co also occurred.

At the Berg Aukas site, the V-rich mine tailings are $>30$ year old, but most $\mathrm{V}$ remains in the primary $\mathrm{V}$ mineral descloizite, embedded in a carbonate matrix while relatively small amounts of released $\mathrm{V}$ have been incorporated into hematite. At this site, the iron content is low because there were almost no $\mathrm{Fe}$ - sulfides in the initial tailings material. Released $\mathrm{Zn}$ and $\mathrm{Pb}$ were incorporated into the carbonate minerals smithsonite and cerussite, which are less stable from an environmental viewpoint.

Finally, at the Kombat Fe-rich mine tailings which are about 5 years old, As released from pyrite has been incorporated into hematite. However, $\mathrm{Cu}$ released by dissolution of chalcopyrite and bornite has precipitated as malachite and cerussite, which are also much less stable than hematite. Formation of hematite, which seems to be fast under tropical climate conditions, is favorable for immobilization of contaminants released into pore water, which do not form carbonate minerals. In contrast, contaminants incorporated into secondary carbonates can be mobilized relatively easily, especially when their gastric bioavailability is considered. Presented results are consistent with findings from other countries with similar climatic conditions, e.g., Southwest of the USA, Mexico, and Tunisia, where high temperature and distinct dry and rainy periods occur. Compared to tropical and subtropical 
climate conditions, secondary hematite is not generally formed under moderate climate conditions.

\section{ACKNOWLEDGMENTS}

The research in Zambia was financed by a grant from the Czech Science Foundation (GACR 205/08/0321/1); the research in Namibia was financed by a grant from the Czech Science Foundation (GACR P210/12/1413).

\section{REFERENCES}

Blowes, D. W., Ptacek, C. J., Jambor, J. L., and Weisener, C. G. (2003). "The geochemistry of acid mine drainage," in Environmental Geochemistry, Treatise on Geochemistry, Vol. 9, ed B. S. Lollar (Amsterdam: Elsevier), 149-204.

Bolanz, R. M., Wierzbicka-Wieczorek, M., Čaplovičová, M., Uhlík, P., Göttlicher, J., Steininger, R., et al. (2013). Structural Incorporation of $\mathrm{As}^{5+}$ into hematite. Environ. Sci. Technol. 47, 9140-9147. doi: 10.1021/es3 $05182 \mathrm{c}$

Boullet, M. P., and Larocque, A. C. (1998). A comparative mineralogical and geochemical study of sulfide mine tailings at two sites in New Mexico, USA. Environ. Geol. 33, 130.

Catalano, J. G., Zhang, Z., Park, C., Fentner, P., and Bedzyk, M. J. (2007). Bridging arsenate surface complexes on the hematite (012) surface. Geochim. Cosmochim. Acta 71, 1883-1897. doi : 10.1016/j.gca.2007.01.015

Cornelis, G., Johnson, A. C., van Gerven, T., and Vandecasteele, C. (2008). Leaching mechanism of oxyanionic metalloid and metal species in alkaline solid wastes: a review. Appl. Geochem. 23, 955-976. doi: 10.1016/j.apgeochem.2008. 02.001

Deane, J. G. (1995). The Structural Evolution of the Kombat Deposits. Otavi Mountainland: Communications of the Geological Survey of Namibia, Vol. 10, 99-107.

Dixit, S., and Hering, J. G. (2003). Comparison of $\operatorname{arsenic}(\mathrm{V})$ and $\operatorname{arsenic}(\mathrm{III})$ sorption onto iron oxide minerals: implications for arsenic mobility. Environ. Sci. Technol. 37, 4182-4189. doi: 10.1021/es030309t

Dokoupilová, P., Sracek, O., and Losos, Z. (2007). Geochemical behaviour and mineralogical transformations during spontaneous combustion of a coal waste pile in Oslavany, Czech Republic. Mineral. Mag. 71, 443-460. doi: 10.1180/minmag.2007.071.4.443

Dold, B., and Fontboté, L. (2001). Element cycling and secondary mineralogy in porphyry copper tailings as a function of climate, primary mineralogy, and mineral processing. J. Geochem. Explor. 74, 3-55. doi: 10.1016/S03756742(01)00174-1

Dold, B., and Fontboté, L. (2002). A mineralogical and geochemical study of element mobility in sulphide tailings of Fe oxide $\mathrm{Cu}-\mathrm{Au}$ deposits from the Punta del Cobre belt, northern Chile. Chem. Geol. 189, 135-163. doi: 10.1016/S00092541(02)00044-X

Ettler, V., Mihaljevič, M., Kříbek, B., and Majer, V., Šebek, O. (2011). Tracing the spatial distribution and mobility of metal/metalloid contaminants in the vicinity of the Nkana copper smelter, Copperbelt, Zambia. Geoderma 164, 73-84. doi: 10.1016/j.geoderma.2011.05.014

Filip, J., Zbořil, R., Schneeweiss, O., Zeman, J., Černík, M., Kvapil, P., et al. (2007). Environmental applications of chemically-pure natural ferrihydrite. Environ. Sci. Technol. 41, 4367-4374. doi: 10.1021/es0 $62312 \mathrm{t}$

Flakova, R., Zenisova, Z., Sracek, O., Krcmar, D., Ondrejkova, I., Chovan, M., et al. (2012). The behavior of arsenic and antimony at Pezinok mining site, southwestern part of the Slovak Republic. Environ. Earth Sci. 66, 1043-1057. doi: 10.1007/s12665-011-1310-7

Giménez, J., Martínez, M., de Pablo, J., Rovira, M., and Duro, L. (2007). Arsenic sorption onto natural hematite, magnetite, and goethite. J. Hazard. Mater. 141, 575-580. doi: 10.1016/j.jhazmat.2006.07.020

Hayes, S. M., Root, R. A., Perdrial, N., Maier, R. M., and Chorover, J. (2014). Surficial weathering of iron sulfide mine tailings under semi-arid climate. Geochim. Cosmochim. Acta 141, 240-257. doi: 10.1016/j.gca.2014. 05.030

International Organization for Standartization. (1995). Soil Quality: Extraction of Trace Elements in Aqua Regia. Geneva: ISO.
Jamieson, H. E. (2011). Geochemistry and mineralogy of solid mine waste: essential knowledge for predicting environmental impact. Elements 7, 381-386. doi: 10.2113/gselements.7.6.381

Langmuir, D. (1997). Aqueous Environmental Geochemistry. Upper Saddle River, NJ: Prentice Hall, 600.

Manning, B. A., Fendorf, S. E., and Goldberg, S. (1998). Surface structures and stability of arsenic(III) on goethite: spectroscopic evidence for innersphere complexes. Environ. Sci. Technol. 32, 2383-2388. doi: 10.1021/es98 02201

Mapani, B., Ellmies, R., Kamona, F., Kř́bek, B., Majer, V., Knésl, I., et al. (2010). Potential human health risks associated with historic ore processing at Berg Aukas, Grootfontein are, Namibia. J. Afr. Earth Sci. 58, 634-647. doi: 10.1016/j.jafrearsci.2010.07.007

Mendelsohn, F. (1961). The Geology of the Northern Rhodesian Copperbelt. London: Macdonald and Co., 523.

Meunier, L., Walker, S. R., Wragg, J., Parson, M. B., Koch, I., Jamieson, H. E., et al. (2010). Effects of soil composition and mineralogy on the Bioaccessibility of arsenic from mine tailings and soil in gold mine district of Nova Scotia. Environ. Sci. Technol. 44, 2667-2674. doi: 10.1021/es9035682

Othmani, M. A., Souissi, F., Bouzahzah, H., Bussiere, B., Ferreira da Silva, E. F., and Benzaazoua, M. (in press). The flotation tailings of the former $\mathrm{Pb}-\mathrm{Zn}$ mine of Ouiref (NW Tunisia): mineralogy, mine drainage prediction, basemetal speciation assessment and geochemical modeling. Environ. Sci. Pollut. Res. doi: 10.1007/s11356-014-3569-1

Parviainen, A., Lindsey, M. B. J., Pérez-López, R., Gibson, B. D., Ptacek, C. J., Blowes, D. W., et al. (2012). Arsenic attenuation in tailings at a former Cu-W-As mine, SW Finnland. Appl. Geochem. 27, 2289-2299. doi: 10.1016/j.apgeochem.2012.07.022

Rainaud, C., Masters, S., Armstrong, R. A., and Robb, L. J. (2005). Geochronology and nature of the Palaeoproterozoic basement in the Central African Copperbelt (Zambia and the Democratic republic of Kongo), with regional implications. J. Afr. Earth Sci. 42, 1-32. doi: 10.1016/j.jafrearsci.2005. 08.006

Rauret, G., Lopez-Sanchez, J. F., Sahuquillo, A., Rubio, R., Davidson, C., Ure, A., et al. (1999). Improvement of the BCR three step sequential extraction procedure prior to the certification of new sediment and soil reference materials. J. Environ. Monit. 1, 57-61. doi: 10.1039/a807854h

Romero, F. M., Armienta, M. A., and González-Hernández, G. (2007). Solid-phase control on the mobility of potentially toxic elements in an abandoned lead/zinc mine tailings impoundment, Taxco, Mexico. Appl. Geoch. 22, 109-127. doi: 10.1016/j.apgeochem.2006.07.017

Salzsauler, K. A., Sidenko, N. V., and Sheriff, B. L. (2005). Arsenic mobility in alteration products of sulphide-rich, arsenopyrite-bearing mine wastes, Snow Lake, Manitoba, Canada. Appl. Geoch. 20, 2303-2314. doi: 10.1016/j.apgeochem.2005.06.007

Singh, D. B., Prasad, G., and Rupainwar, D. C. (1996). Adsorption technique for treatment of As(V)-rich effluents, Colloid. Surf. A 111, 49-56. doi: 10.1016/0927-7757(95)03468-4

Sracek, O., Mihaljevič, M., Kř́ibek, B., Majer, V., Filip, J., Vaněk, A., et al. (2014a). Geochemistry and mineralogy of vanadium in mine tailings at Berg Aukas, northeastern Namibia. J. Afr. Earth Sci. 96, 180-189. doi: 10.1016/j.jafrearsci.2014.04.003

Sracek, O., Mihaljevič, M., Kř́ibek, B., Majer, V., Filip, J., Vaněk, A., et al. (2014b). Geochemistry of mine tailings and behavior of arsenic at Kombat, northeastern Namibia. Environ. Monit. Assess. 186, 4891-4903. doi: 10.1007/s10661-0143746-1

Sracek, O., Mihaljevič, M., Kř́ibek, B., Majer, V., and Veselovský, F. (2010a). Geochemistry and mineralogy of $\mathrm{Cu}$ and $\mathrm{Co}$ in mine tailings at the Copperbelt, Zambia. J. Afr. Earth Sci. 57, 14-30. doi: 10.1016/j.jafrearsci.2009. 07.008

Sracek, O., Veselovský, F., Kříbek, B., Malec, J., and Jehlička, J. (2010b). Geochemistry, mineralogy and environmental impact of precipitated efflorescent salts at the Kabwe Cu- Co chemical leaching plant in Zambia. Appl. Geochem. 25, 1815-1824. doi: 10.1016/j.apgeochem.2010. 09.008

Vaněk, A., Ettler, V., Skipalová, K., Novotný, J., Penížek, V., Mihaljevič, M., et al. (2014). Environmental stability of the processing waste from sulfide mining districts of Namibia-A model rhizosphere solution approach. J. Geochem. Explor. 144, 421-426. doi: 10.1016/j.gexplo.2013.10.018 
Vu, H. P., Shaw, S., Brinza, L., and Benning, L. G. (2013). Partitioning of $\mathrm{Pb}(\mathrm{II})$ during goethite and hematite crystallization: implications for $\mathrm{Pb}$ transport in natural systems. Appl. Geoch. 39, 119-128. doi: 10.1016/j.apgeochem.2013.10.001

Conflict of Interest Statement: The author declares that the research was conducted in the absence of any commercial or financial relationships that could be construed as a potential conflict of interest.

Received: 16 September 2014; accepted: 08 December 2014; published online: 05 January 2015
Citation: Sracek $O$ (2015) Formation of secondary hematite and its role in attenuation of contaminants at mine tailings: review and comparison of sites in Zambia and Namibia. Front. Environ. Sci. 2:64. doi: 10.3389/fenvs.2014.00064

This article was submitted to Groundwater Resources and Management, a section of the journal Frontiers in Environmental Science.

Copyright (c) 2015 Sracek. This is an open-access article distributed under the terms of the Creative Commons Attribution License (CC BY). The use, distribution or reproduction in other forums is permitted, provided the original author(s) or licensor are credited and that the original publication in this journal is cited, in accordance with accepted academic practice. No use, distribution or reproduction is permitted which does not comply with these terms. 